ТУРКОВ Егор Анатольевич - студент 2-го курса факультета политологии Московского государственного университета им. М.В. Ломоносова (119991, Россия, г. Москва, Ломоносовский $n$-кт, 27, кopn. 4; turegor1209@gmail.com)

Научный руководитель: А.В. Селезнева, д.полит.н., доцент кафедры социологии и психологии политики

\title{
ВОСПРИЯТИЕ ВЕЛИКОЙ ОТЕЧЕСТВЕННОЙ ВОЙНЫ РОССИЙСКИМИ СТАРШЕКЛАССНИКАМИ: АНАЛИЗ СИМВОЛОВ И ОБРАЗОВ
}

\begin{abstract}
Аннотация. В работе представлены итоги исследования восприятия российскими старшеклассниками Великой Отечественной войны, а также связанных с ней символов и образов. Автор приходит к выводу, что в массовом сознании школьников война теряет символическое значение. Так, Россия ассоциируется с Победой у малого числа респондентов. Они не рассматривают участников событий 1941-1945 гг. как идеальных граждан. В связи с этим мы предполагаем, что Великая Отечественная война утрачивает значение основы отечественной политики идентичности.
\end{abstract}

Ключевые слова: Великая Отечественная война, российские старшеклассники, символы, политические образы, политическое восприятие, гражданственность, патриотизм

Введение. Исследование образно-символического аспекта восприятия российскими старшеклассниками Великой Отечественной войны имеет как научно-теоретическое, так и практическое значение. Во-первых, уже в XX в. представления о войне стали неотъемлемым элементом массового политического сознания российских граждан вследствие значимости Победы и подвига советского народа. Исследование отношения к ней российских школьников, склонность выделять ее на фоне других событий в качестве символа страны позволяет определить характер макрополитической идентичности.

Во-вторых, символический и ценностный потенциал событий 1941-1945 гг. стал фундаментом политики идентичности и политики памяти, реализуемых в нашей стране [Малинова 2015б]. Изучение восприятия Великой Отечественной войны позволяет корректировать взаимодействие государства, общества и молодежи в символическом пространстве.

B-третьих, российская государственная молодежная политика направлена на формирование патриотизма и гражданственности. Достижению этого результата способствует создание идеалов в лице героев прошлого, в первую очередь защитников страны в годы Великой Отечественной войны. Анализ отношения к ним молодежи также предоставляет возможность выявить эффективность деятельности государства и общества в данном направлении.

Теоретико-методологииеские основания исследования. Данное исследование было проведено в рамках политико-психологического подхода, который предполагает не только выявление структуры, фиксацию состояния политического сознания, но и определение его детерминистических связей с социальнополитическим контекстом [Селезнева 2011: 44], а также ключевых трендов. Массовое политическое сознание рассматривается как производное от взаимодействия множества факторов, один из которых - транслируемые государством в рамках политики идентичности и исторической политики символы и образы. Изучение их «следов» в политическом сознании предполагает опору на специальные теорию и методологию. 
Основанием данного исследования служит теория политического восприятия [Психология... 2012; Шестопал, Смулькина 2018; Шестопал 2018]. Согласно данному подходу, политическое восприятие отличается от социального восприятия ${ }^{1}$ направленностью на оценочную интерпретацию деятельности лидеров, более выраженным взаимовлиянием когнитивных и эмоциональных компонентов перцепции, опосредованным характером [Психология... 2012: 10]. Результатом этого психического процесса становится политический образ, который «представляет собой отражение реальных характеристик объекта восприятия (конкретного политика), а также проекцию ожиданий субъектов восприятия - российских граждан» [Образы государств... 2008]. Эмоционально-аффективная природа образов, а также влияние на них коммуникативного, темпорального, пространственного и иных факторов [Селезнева 2018] придают им неустойчивый характер. Тем не менее политические образы выполняют функцию формирования политической картины мира [Шестопал 2002] и оказывают значительное воздействие на поведенческий аспект психики человека.

Структурирующее воздействие на политическое сознание оказывают также символы, которые мы вслед за теоретиками символической политики определяем как априорные смысловые структуры, которые помогают усваивать сообщения, редуцируя их к заранее известному [Малинова 2013], а также обладают высоким идентификационным потенциалом [Евгеньева, Селезнева 2017]. В данной работе мы рассматриваем их как результат применения символической власти [Бурдье 2007] и реализации символической политики [Edelman 1985].

Таким образом, мы акцентируем внимание на анализе массового политического сознания молодежи. В качестве источника его содержания мы рассматриваем символическую политику государства.

Характеристика исследования. В рамках эмпирического исследования методом формализованного интервью были опрошены 750 учащихся 10-11-х классов в возрасте 15-18 лет, получающих образование в 9 субъектах России: Москве, Московской, Тверской, Тульской, Липецкой, Иркутской обл., Краснодарском, Приморском краях, Республике Северная Осетия - Алания. Респонденты ответили на открытые вопросы, посвященные символам России и образцам гражданственности, что позволило проанализировать символы и образы Великой Отечественной войны, а также выявить фон их присутствия в политическом сознании школьников.

Восприятие Великой Отечественной войны в России в XXI в. Формирование представлений о Великой Отечественной войне стало одним из базовых элементов гражданско-патриотического воспитания современной российской молодежи, конструирования ее идентичности [Малинова 2015б]. В государственно-политическом дискурсе война приобрела значение символа героизма народа, а Победа - торжества добра над злом, России над Западом. Массовое сознание может принимать, отвергать или трансформировать символы, которые транслируют государство и иные субъекты символической политики [Евгеньева, Селезнева 2017: 49], в связи с чем перед ними стоит задача корректировать взаимодействие с обществом [Малинова 2015a].

Изменения в восприятии событий обусловлены в том числе поколенческим

1 Термин введен американским психологом Дж. Брунером в 1977 г. в работе «Психология познания». 
фактором. Этот тезис подтверждают исследования ФОМа ${ }^{1}$ и ВЦИОМа ${ }^{2}$, проведенные в 2017 и 2018 гг. соответственно.

Опрос ФОМа показал, что для населения России в возрасте 18-30 лет Великая Отечественная война ассоциируется с гордостью за страну, чувством патриотизма (29\%), а также скорбью (18\%).

Исследование ВЦИОМа продемонстрировало низкий уровень знаний о событиях 1941-1945 гг. и когнитивную бедность образа Великой Отечественной войны. Так, $60 \%$ респондентов в возрасте 18-24 лет не смогли назвать правильную дату ее начала.

Вместе с тем Великая Отечественная война вызывает чувство гордости у 72,2\% современной российской молодежи [Селезнева 2014: 134].

Таким образом, представления молодежи о Великой Отечественной войне носят эмоционально насыщенный и одновременно когнитивно бедный характер. В сочетании с влиянием внешних факторов, таких как распространение ложной и негативной информации о героях войны, популяризация предателей СССР и т.д., особенности представлений молодежи обусловливают высокую вероятность их трансформации.

Результаты исследования. Исследование выявило лакуны в символическом восприятии Великой Отечественной войны российскими старшеклассниками. Из 47,6\% респондентов, которые смогли привести пример символов России, только 0,7\% школьников указали в таком качестве войну. Более популярными были следующие ответы: наука и технологии (16,5\%), культура и искусство $(12,8 \%)$, оборона, армия и вооружение $(3,7 \%)$, государственные символы $(1,6 \%)$.

Симптоматичным фактом является отсутствие конкретных примеров в приведенных ответах. По нашему мнению, это свидетельствует об отсутствии трансформации знания в переживание [Рубинштейн 2020], т.е. о несущественности символов России и представлений о ней для старшеклассников. Этот тезис подтверждает отсутствие ответов на данный вопрос в анкетах большинства опрошенных $(52,4 \%)$. В перспективе указанная особенность массового политического сознания может привести к кризису макрополитической идентичности.

Таким образом, полученные данные свидетельствуют о несформированности войны-символа в массовом политическом сознании российских старшеклассников. Кроме того, они ставят проблему поиска новых источников символов российской исторической политики и политики идентичности, адекватных представлениям молодежи. Вероятно, результаты деятельности субъектов отечественной культуры могут постепенно заменить военные достижения в качестве основ для укрепления российского макрополитического сообщества.

Проблему качественного использования символического потенциала Великой Отечественной войны также ставят ответы на вопрос: «Кого из современников или деятелей прошлого Вы могли бы назвать образцовым гражданином, примером гражданственности?» Только 4,4\% респондентов указали военачальников, таких как А.В. Суворов, М.И. Кутузов, Г.К. Жуков и т.д., а $2,2 \%$ - героев войн. Таким образом, военные не пользуются популярностью у современных российских старшеклассников, что указывает на возможность разрушения «пантеона».

Военных вытесняют другие деятели. Так, 44,2\% ответивших на вопрос

1 Война и Победа. Правдиво или нет освещается история войны в нашей стране? Опрос ФОМа от 8 мая 2017 г. Доступ: https://fom.ru/Proshloe/13313 (проверено 13.04.2020).

2 Память о войне: история и мифы. Опрос ВЦИОМа от 22 июня 2018 г. Доступ: https:// wciom.ru/index.php?id=236\&uid=9176 (проверено 13.04.2020). 
указали отечественных императоров и политиков (Петра I, Екатерину II, Александра III, П.А. Столыпина, М.М. Сперанского), 15,3\% - деятелей науки и искусства, 8\% - общественных деятелей и журналистов, 18,2\% - «другое». К «другому» относятся Е. Шульман, Б. Обама, Л. Яшин и т.д. 57,9\% респондентов не смогли привести пример образцов гражданственности.

Таким образом, несмотря на относительно недавнее изучение событий 1941-1945 гг. в школе, в сознании школьников не произошла актуализация символического и образного аспектов восприятия Великой Отечественной войны. На фоне неспособности более половины респондентов привести примеры символов страны этот факт свидетельствует о слабом влиянии символической политики на политическое сознание российской молодежи. Предполагаем, что полученные данные обладают симптоматичным характером в условиях попыток российских государственных структур выстроить политику идентичности на основе символического потенциала Великой Отечественной войны.

Выводы. Итак, события 1941-1945 гг. воспринимаются в качестве символа России крайне ограниченным числом респондентов; абсолютное большинство опрошенных не указали защитников Отечества в качестве образцов гражданственности. Результаты свидетельствуют о низком уровне сформированности символического аспекта восприятия Великой Отечественной войны в массовом политическом сознании российских старшеклассников.

Полученные данные можно объяснить как длительным периодом эксплуатации символов войны и Победы, так и недостаточно качественным и продуманным характером их использования в символической политике государственных структур и общества. Итогом становится не только утрата интереса к событиям 1941-1945 гг., которая естественна для поколения, живущего спустя 75 лет после окончания военных действий, но и постепенная деформация идентичности, протекающая вне контроля субъектов политики. Следствием может стать неудача дальнейших попыток социальных институтов выстроить коммуникацию с молодежью и транслировать ей представления о прошлом России. В связи с этим перед субъектами данного направления политической деятельности встает задача ее концептуального пересмотра и реформирования, в т.ч. с учетом особенностей поколения $Z$ : индивидуализма, быстрой скорости потребления информации, клипового, или фрагментарного мышления и др. [Кулакова 2018].

\section{Список литературы}

Бурдье П. 2007. Социология социального пространства. М.: Институт экспериментальной социологии; СПб: Алетейя. 288 с.

Евгеньева Т.В., Селезнева А.В. 2017. Трансформация национально-государственной идентичности российской молодежи в постсоветский период: ценностные основания и символические репрезентации. - Полития. № 4. С. 48-64.

Кулакова А.Б. 2018. Поколение Z: теоретический аспект. - Вопросы территориального развития. № 2(42). С. 1-10.

Малинова О.Ю. 2013. Конструирование смыслов: Исследование символической политики в современной России. М.: ИНИОН РАН. $421 \mathrm{c.}$

Малинова О.Ю. 2015а. Актуальное прошлое: Символическая политика властвующей элиты и дилеммы российской идентичности. М.: Политическая энциклопедия. 207 с.

Малинова О.Ю. 2015б. Великая Отечественная война как символический ресурс: эволюция отображения в официальной риторике 2000-2010 гг. - Россия и современный мир. № 2. С. 6-29. 
Образы государств, наций, лидеров (под ред. Е.Б. Шестопал). 2008. М.: Аспект Пресс. 286 c.

Психология политического восприятия в современной России (под ред. Е.Б. Шестопал). 2012. М.: РОССПЭН. 311 с.

Рубинштейн С.Л. 2020. Основы общей психологии. СПб: Питер. 713 с.

Селезнева А.В. 2011. Методология исследования политических представлений и ценностей. - Вестник Московского университета. Сер. 12. Политические науки. № 2. С. 42-53.

Селезнева А.В. 2014. Молодежь в современной России: политические ценности и предпочтения. М.: АРГАМАК-МЕДИА. 276 с.

Селезнева А.В. 2018. Образ президента России В.В. Путина в сознании российских граждан. - Русская политология. № 7(2). С. 4-11.

Шестопал Е.Б. 2002. Политическая психология: учебник для вузов. М.: ИНФРА-М. 448 c.

Шестопал Е.Б. 2018. Особенности использования психологических методов для изучения политического восприятия. - Социальная психология и общество. № 9. C. 81-90.

Шестопал Е.Б., Смулькина Н.В. 2018. Факторы восприятия постсоветских стран в современном обществе. - Полис. Политические исследования. № 1. C. 26-44.

Edelman M. 1985. The Symbolic Uses of Politics. Urbana: University of Illinois Press. $201 \mathrm{p}$.

TURKOV Egor Anatol'evich, second-year student at the Faculty of Political Science, Lomonosov Moscow State University (bld. 4, 27 Lomonosovsky Ave, Moscow, Russia, 119991; turegor1209@gmail.com)

Research adviser: A.V. Selezneva, Dr.Sci. (Pol.Sci.), Associate Professor of the Chair of Sociology and Psychology of Politics

\title{
PERCEPTION OF THE GREAT PATRIOTIC WAR BY RUSSIAN HIGH SCHOOL STUDENTS: ANALYSIS OF THE SIMBOLS AND IMAGES
}

\begin{abstract}
The work considers the results of the analysis of the imaginal and symbolic aspects of the perception of the Great Patriotic war by Russian high school students. The relevance of this research is due to the key significance of the events of 1941-1945 in the formation of the identity of the Soviet people and Russian nation. The results presented in this paper indicate that the process of loss of symbolic content by the Great Patriotic War is destructive for the Russian political consciousness. A small number of respondents associate modern Russia with Victory and mention War heroes as examples of citizenship. The data obtained correlate positively with the results of surveys conducted by WCIOM and FOM, according to which most of the respondents do not have basic knowledge about the War. These indicators may be due to the fragmented historical policy implemented in Russia, as well as the long-term exploitation of the symbolic potential of the Great Patriotic War without involving other events in Russian history.

Thus, the subjects of identity politics are faced with the task of finding new grounds for integrating Russian society, as well as rethinking the course that has been pursued for thirty years.
\end{abstract}

Keywords: Great Patriotic War, Russian high school students, symbols, political images, political perception, civic consciousness, patriotism 